\title{
A Research on Second Language Acquisition and College English Teaching
}

\author{
Changyu Li \\ Foreign Language Department, North China Institute of Science and Technology \\ Beijing 101601, China \\ E-mail: frank1588@163.com
}

\begin{abstract}
It was in 1970s that American linguist S.D. Krashen created the theory of "language acquisition". And the theories on second language acquisition were proposed based on the study on the second language acquisition process and its rules. Here, the second language acquisition process refers to the process in which a learner with the mastery of his mother language learns another language without its social environment. Due to the close relationship between second language acquisition research and language teaching, the relevant acquisition theories are of great importance for college English teaching, during which teachers are expected to base their teaching on second language acquisition theories to study the rules of college English teaching, to reform the current teaching patterns and methods and to improve teaching quality. This is a significant project to study carefully for college English teachers as well as second language acquisition researchers.
\end{abstract}

Keywords: Language acquisition, Second language, College English teaching, Teaching quality

\section{A Research on Second Language Acquisition Theories}

\subsection{Language Input Hypothesis}

Here, input means the language information learners receive from the language environment. According to the second language acquisition theory proposed by Krashen, understandable language input is the key to language acquisition. This theory was expressed by Krashen as " $i+1$ ", that is, a language learner won't achieve the " $i+1$ " level until he realizes the language input process beginning from this existing language knowledge $i$. According to this theory, learners mainly learn one language in two channels: one is acquisition and the other is learning. Here the former means that a learner takes in and then uses a language unconsciously through language communication practice while the latter means that a conscious study and understanding of a language. That is to say, acquisition is of greater importance than learning, hence emphasizing the significance of putting students into a language learning environment with feedback system to guarantee their contact with a large amount of understandable language input during our college English teaching.

\subsection{Language Output Hypothesis}

Output here means that learners achieve their language communication purpose by practicing with the language knowledge and skills they have obtained and sending understandable output. Wells defined this class interaction as a collaborative activity among language input, language information acceptance and language environment, which shows the importance of language acquisition environment and learners' internal encouragement system. Accordingly, in college English teaching, teachers should establish an interactive class pattern in which students will have opportunities to deal with the language input they accept, apply their language skills to communication and adjust their learning strategies.

\subsection{Language Internal Syllabus}

According to the theory of language internal syllabus, language learners' acquisition process should be gradual. Since the language acquisition effect will be influenced by the learners' intelligence, personality, learning motivation, interest and so on, language learning is a progressive, internal and natural acquisition process. Therefore, college English teachers are expected to give students some necessary guidance and instructions as well as encouragement and help to help them solve problems in learning, relieve their impatience, depression and anxiety as well as design language learning activities in a better way.

\section{Influencing Factors of Second Language Acquisitions}

A variety of factors may influence second language acquisition, including teaching materials, syllabus, teaching means and methods, teaching quality, differences in personality and learners themselves and so on. According to my study on second language acquisition theories, I'll only focus on the influences of learners' differences in personality, their motivation, attitudes as well as intelligence on language acquisition.

\subsection{Differences in Personality}

In Ellis' theory, "language acquisition through second language teaching attempts will indirectly lead to higher 
acquisition efficiency in class no matter it is based on formal teaching or created conditions. Only by learning about the learners' different personalities and some necessary influencing factors of second language acquisition can we have a real control of teaching and teaching reform. It doesn't only depend on the teacher's teaching standard, teaching materials, teaching means but the learner's different personalities whether he will succeed or not. As is shown in our investigation, a successful language learner will be able to adjust his strategies to his own cognition style, learning task, basis and so on. Actually it is safe to say that positive psychological quality, stable mood, strong will and self-control power will influence a learner's choice of learning strategies, hence affecting his efficiency and result. A student lacking in self-confidence usually cannot express their ideas fluently or do well in language communication, cannot control his own feelings or have negative emotional strategies. On the contrary, a confident student has natural expression, light mood, strong activity and courage to take risks. Therefore, such a student will try to seize every opportunity to practice and relieve his depression, hence achieving better efficiency and result. In my opinion, personality influences the choice of language learning strategies, during which an excellent learner is able to choose the strategies fit for him. Therefore, teachers should find out students' differences in personality, establish and perfect different teaching targets based on them and take specific measures for different students.

\subsection{Learning Motivation and Attitudes}

Learning motivation and attitudes are emotional factors influencing the result of second language acquisition. First of all, learning motivation is a strong internal drive for language learning. Psychologically, teaching effect is closely related to learning motivation and interest, which determines whether a learner would like to spend more time learning English. Besides, learning motivation and attitudes are closely associated with language learning strategies, hence influencing language learning effect to some degree. Generally speaking, the stronger learning motivation is, the more passion learners have for learning, the more lasting the learning activity will be, the more difficulties can be overcome. Therefore, teachers are supposed to do a lot in teaching contents, teaching methods, teaching organization and teaching supervision in order to create a pleasant, natural and harmonious language learning environment. In addition, based on their grades, teacher should encourage students to have more creative thinking in order to develop their internal potentials, stimulate their diversified language learning motivation and demands, establish their confidence, help them to set up an internal self-stimulating system and improve their learning motivation finally. Only in this way can we help to form a virtuous circle between motivation and success and then to promote students' language acquisition effectively.

\subsection{Intellectual Factors}

To some degree, intellectual factors influence learners' achievements in second language acquisition, mainly in their learning efficiency. In my opinion, intelligence refers to the abilities helpful to language learning, such as memory ability, imitation ability, analysis and judgment ability, the ability to solve problems independently, organization and summary ability, self-assessment ability as well as a potential ability for language learning. Accordingly, teachers should take the heuristic method to develop students' intelligence, expand their views, develop their potentials and improve their cognitive abilities.

\section{Significance of the Research on Second Language Learning Theories in College English Teaching}

Students in English-speaking countries have a very good environment for English learning which is filled with real circumstances, expressions, gestures and body language. However, college English teaching is conducted in an unnatural condition, in which students have no access to a favorable language environment except their limited class hours. Thus, the study on second language learning theories seems particularly important for college English teaching. Based on my research, I would like to briefly elaborate on the significance of these theories on our present teaching activities.

\subsection{Helping to Lay down English Teaching Objectives and Choose Teaching Materials}

As is suggested in second language learning theories, the nature of language input, learners' acquisition process as well as the rules of language acquisition should be taken into consideration when establishing teaching plans in order to set up a student-centered language learning pattern and to design specific class activities and teaching skills. Besides, real, interesting, relevant and various language subject matters and materials should be chosen to put students into contact with a large amount of understandable language input, offer more real language communication opportunities, stimulate students' enthusiasm for learning and therefore to improve their efficiency and achievement in language learning.

\subsection{Helping Teachers to Flexibly Employ Proper Teaching Methods}

First of all, the indirect method can be turned to. Objects, pictures, gestures, expressions as well as actions can be made use of to design certain English teaching method and process and enrich language learning environment.

Second, the listening-speaking method can be used. Since the language acquisition process is one involving stimulation, response, imitation and enhancement, real-life listening and speaking practice will enable students to listen and imitate repeatedly, to learn pure pronunciation and intonation. This method, conforming to the rules of language acquisition as well as emphasizing language input, helps to create language environment. 
Third, the audio-visual method or the situational method can be employed, in which more importance is attached to language acquisition rules, a large amount of language input, the creation of teaching situations as well as the importance of vision in language learning.

Finally, the communicative method can also be used. Language acquisition depends on a large amount of understandable language input, the gain of which involves the learners' extensive contact with language materials and their participation in communication in person to convert what they have got into some understandable materials. Therefore, this method puts more emphasis on oral practice, employing real and natural language, cultivating students' communicative abilities, which basically complies to a natural process of language acquisition. Without any doubt, proper and flexible English teaching methods help to imitate the whole language acquisition process, to create language environment, to stimulate students to take an active part in communicative activities so as to expand their language input methods and channels and improve their language acquisition efficiency.

\section{Revelation and Application of the Research on Second Language Acquisition Theories to College English Teaching Reform}

According to language acquisition principles, the acquisition process is a psychological one in which learners participate actively and a process in which learners store and arrange the language input they have acquired and put it into practice. Only with a favorable language environment as well as language input will language acquisition be fulfilled. In English teaching, the creation of language environment should be emphasized in which some characteristics in irregular language learning environment are introduced into regular language learning environment to achieve better teaching effect. Therefore, it is a particularly important guarantee and the tendency of college English teaching reform during the second language acquisition process to create language environment, offer language input, establish a dynamic teaching pattern.

\subsection{Establishing Student-Centered Dynamic Class Teaching Pattern}

According to Ellis R., "the failure to provide learners with opportunities to communicate naturally will separate them from the main channel to gain language materials and hence to hold up the acquisition process". Language acquisition is a systematic process involving teachers, students and teaching materials. A favorable class teaching and language acquisition environment, to some degree, results in the success in language acquisition. However, in our traditional English classes where the teacher's role is excessively emphasized, language learning is regarded as the acquisition of knowledge instead of skills. Accordingly, teachers are quite lonely at class, emphasizing the explanation and practice of language knowledge and rules while neglecting the opportunities for students to get in touch with as well as apply language knowledge and skills in practice, while students don't listen to them attentively. This pattern, of course, will affect the development and improvement of students' English proficiency. In my opinion, a student-centered dynamic class teaching pattern must be established, in which teachers speak English acceptable for students, control the whole language teaching and acquisition process directly, employ a variety of teaching skills and methods including teacher-student communication, group discussion and report, presentation, individual report and performance and so on in order to stimulate students' enthusiasm for participating in class activities. In this way, students will get more understandable language input, have contact with many kinds of understandable language and hence to have their language acquisition goal achieved.

\subsection{Establishing "Four-in-One" College English Teaching Method}

As is required in language acquisition rules, a large amount of practice teaching and learners' independent practice should be included in college English teaching since only in this way can they solidify their language knowledge and acquire language skills. Therefore, the "four-in-one" teaching method reflects the theories and rules of second language acquisition and highlights the objectives of language teaching.

First, offering a favorable language teaching environment. In college English teaching, a dynamic language environment should be offered first, in which the design of class teaching sections and techniques is emphasized, including getting familiar with teaching contents, collecting relevant materials, preview, introduction, establishing relevant teaching situations, group discussion, debates, assignments and so on.

Second, emphasizing class teaching drills. In college English classes, practice and drills are focused on, in which teachers are directors while students are actors. Students' errors in language application and communication should be corrected timely at the right time.

Third, instructing students to have personalized learning. Andrew D. Cohen (1990) pointed out that the success in language learning is based on learners themselves, especially their own factors and abilities to make full use of learning opportunities. College English learning should be the development in the direction of students' active and independent learning and practice, including English reading in the morning, independent practice at class, finishing assignments, reading English books, listening to English broadcast, participating in second class activities, online learning, self-assessment and son on, in order to promote students to learn independently and effectively.

Fourth, enhancing the assessment for students. As is pointed out in College English Curriculum Requirements, 
assessment is an important knot in college English teaching, which includes students' self-assessment, students' assessment for each other, teachers' assessment for students, education administrators' assessment for students and so on. Accordingly, teachers are expected to observe, monitor and assess students' preview, review, phasic review, class activities, extracurricular activities, study documents, online learning, students' self-assessment, students' assessment for each other, interviews with teachers, students' forums, examination results, grades analysis and so on in order to learn about their language learning process and learning effect, to gain teaching feedback, to improve teaching methods and administration, to adjust students' learning strategies as well as to improve teaching quality and learning efficiency.

\subsection{Creating Favorable Language Teaching Environment and Stimulating Learners' Enthusiasm for Language Learning}

According to second language acquisition theories, ideal class teaching should provide a language learning environment with many opportunities to use the target language directly. In the college English teaching process, students' experience and participation play a particularly important role in language learning. Therefore, necessary environment should be created to exert teachers' intervening function, to stimulate learners' activity, to encourage students to participate in communicative activities for solving problems and fulfilling learning tasks, to give learners more access to language and therefore to indulge them in the environment of the target language. For instance, teachers provide a real environment for students by speaking the target language at class, creating role-play activities based on specific situations, organizing and instructing students' group discussion and debates, hence promoting students' cooperative learning, providing a pleasant language acquisition environment, relieving students' anxiety and improving their success rate in language acquisition.

\subsection{Correctly Treating Language Transfer and Fully Considering Learners' Emotional Factors}

Transfer, an important emotional factor in language communication, doesn't refer to the abandoning of one's own emotions, but surpassing it. Nevertheless, college English teachers don't regard language transfer from the perspective of cognitive linguistics and psychology. Due to the shortage of environment required by learners' cognitive and emotional behaviors, it is of no use talking about how to improve their learning efficiency. So it is of great importance to study the influences learners' emotional factors have on college English teaching because it helps to exert their learning potentials, stimulate their interest in language learning and improve their learning effect. If teachers put excessive importance on the cognitive factors of second language learning while neglecting the role of emotional factors, learners have no way to release their emotions and express their feelings, resulting in the separation of cognition from emotion in English teaching. As a result, with confidence-lacking students, dull class atmosphere and low learning spirit, it keeps troubling teachers how to improve English teaching quality.

\section{Conclusion}

In a word, second language acquisition research and college English teaching are auxiliary to each other. As a conscious acquisition process in a social environment without the target language, college English learning involves the development and improvement of language knowledge, language skills and intercultural communication abilities. Therefore, in college English teaching, based on second language acquisition theories, teachers should establish a student-centered class teaching pattern to deliver intercultural communication knowledge, cultivate students' intercultural communication abilities, create language acquisition environment, fully consider students' emotional factors and improve the teaching quality and learning effect of college English.

\section{References}

Colen, A D. (1998). Strategies in Learning and Using a Second Language. New York: Longman.

Cook, V. (1991).Second Language Learning and Teaching. New York: Routledge, Chapman and Hall, Inc.

Ellis, R. (1994).Second Language Acquisition. Oxford: OUP.

Ellis, R. (1985).Understanding Second Language Acquisition. OU.

Higher Educaion Department of the Ministry of Education. (2007). College English Curriculum Requirements. Foreign Language Teaching and Research Press.

Jiang, Zukang. (1999). A Research on Foreign Language Acquisition. Beijing: Foreign Language Teaching and Research Press.

Krashen, S. (1982). Principles and Practice in Second Language Acquisition. Oxford: Pergamon.

Krashen, S. (1981). Second Language Acquisition and Second Language Learning. Oxford: Pergamon.

Mclaughlin, B. (1987). Theories of Second Language Learning. London: Edward Arnold.

O’Malley, J. M. \& Chamot, AU. (1990).Learning Strategies in Second Language Acquisition Cambridge: Cambridge University Press.

Towell, R. \& Hawkins, R. (1994). Approaches to Second Language Acquisition. Clevedon, Philadelphia. 